\title{
Why doubling discourse particles?
}

\section{Introduction}

In this chapter, I want to extend my earlier work on discourse particles as functional heads by providing new evidence from particle doubling. I will argue that the German data on doubling that I will present are explained in a natural way within the unificational theory of focus particles as well as discourse particles developed in Bayer (1996, 1999, 2012, 2018) and in Bayer and Obenauer (2011), Bayer and Trotzke (2015) as well as in Bayer, Häussler and Bader (2016). Particle doubling lends new support to this theory which defends the view that particles of the relevant sort are functional heads.

\section{The particle problem in syntax}

Particles, focus particles as well as discourse particles, have remained a controversial issue in linguistic theory for many years. On one side, they have much in common with adverbs, on the other side, they differ from adverbs by showing both more constrained and more relaxed word orders. Focus particles (FP) like only and even and their correspondents in other languages are usually taken to be adverbs. Especially in the semantic literature not too much attention is given to their syntactic status. Since they are (supposed to be) optional, they are adjoined. Since they are semantically propositional operators, they must be adjoined to sentential domains ( $v \mathrm{P}, \mathrm{TP}$ or $\mathrm{CP}$ ). In cases like He adores only ROSSINI, this is obviously not the case. So it needs some acrobatics to arrive at the LF "For every composer $\mathrm{x}$ that he adores, $\mathrm{x}$ equals Rossini”. Various proposals have been made, which I cannot discuss here in

Notes: This work was supported by grant BA 1178/9-1 of the DFG (German Research Council). My thoughts benefitted from discussions with Sjef Barbiers, Alex Grosu, Rita Manzini, Andreas Trotzke, Yvonne Viesel, Michael Wagner, George Walkden and participants of the 2015 workshop on Freezing held in Tübingen. Written comments by Michael Wagner, Yvonne Viesel, and an anonymous reviewer were of great help. Thanks to Uwe Braun, Marc Meisezahl and Verena Simmler for technical support. Any insufficiencies are in my responsibility.

Josef Bayer, University of Konstanz

https://doi.org/10.1515/9781501505201-005 
detail. Investigations of FPs in German have resulted in roughly two proposals, the "adverb theory" and the "mixed theory". The former, see Jacobs (1983) and Büring and Hartmann (2001), assumes a syntax in which FPs are adjoined sentential operators. Phrases like [DP only ROSSINI] are a big problem, and their existence has even been denied. The latter, see Reis (2005) and Barbiers (2010, 2014), assumes an extension by which FPs can also be adjoined to non-sentential major constituents such as DP, PP etc. Rochemont (2018), following Bayer (1999), uses the term “constituent only" which he distinguishes from "adverbial only". In these aproaches, it remains to be seen how the syntax to semantics mapping works.

With respect to discourse particles (DiP), the dominant theory is also the "adverb theory" by which a DiP is adjoined to a propositional domain. In studies of German, where most of the research on DiPs comes from, DiPs are assumed to be adjoined to $v$ P i.e. a propositional domain. For Italian, researchers are split. Some argue for adverb status, see Manzini (2015), or a special category of "weak adverbs", see Cardinaletti (2011) and Coniglio (2008), others have argued that DiPs are heads which occupy the C-domain, see Munaro and Poletto (2003), Poletto (2000), Poletto and Vanelli (1995), and for criticism Manzini (2015). For German, a straight adverb account is hard to defend. If DiPs are adverb-like, they have undergone grammaticalization and, as a result, have become weak and immobile. ${ }^{1}$ Unlike adverbs, they can, for example, not be displaced, see Thurmair (1989). The projective status of DiPs has been discussed within X-bar theory. Meibauer (1994) finds that various facts speak in favor of head status, but ultimately he leaves the issue undecided.

In my work on FPs, (see Bayer 1996; 1999; 2018), as well as in my work on DiPs (see Bayer 2010; 2012; 2018; Bayer and Obenauer 2011; Bayer and Trotzke 2015), I have continuously argued for an account in which particles have the status of functional heads. Before I will provide new evidence for this hypothesis in section 4, I will give in section 3 a summary of why I believe that this is the most adequate theory, at least for the German data under consideration. ${ }^{2}$

1 According to Manzini (2015), Italian DiPs and adverbs occupy the same positions in the sentence and are not grammaticalized. If so, this would be in strong contrast with German, see Hentschel (1986).

2 Bangla, as studied by Bayer and Dasgupta (2016) and Bayer, Dasgupta and Mukhopadhyay (2014), offers independent evidence for the functional head theory, and so seem to do many other languages. According to $\mathrm{Li}$ (2006: 64), the final particles of Mandarin are "heads of functional projections in the CP domain”, similarly Endo (to appear) for Japanese. For Paul and Pan (2017), Chinese sentence-final particles are head-final complementizers. 


\section{Particles as functional heads}

According to my earlier work, FPs as well as DiPs are not adverbs but syncategorematically introduced heads which project a so-called PARTICLE PHRASE (PrtP). In other words, particles import semantic but no categorial syntactic features. If their sister is of type $v \mathrm{P}$, the resulting PrtP is also of type $v \mathrm{P}$. Importantly, $v \mathrm{P}$ is a propositional domain, i.e. Prt takes scope over a proposition. The general observation is that in pre- $v \mathrm{P}$ position, Prt takes scope once and forever. In other words, the scope cannot be altered by further operations. To see this, consider the English example in (1a) with the structure in (1b).

(1) a. We are required to only study SYNTAX

b. We are required to [ ${ }_{\mathrm{PrtP}}$ only [vp study SYNTAX]]

Since only is syncategorematic, PrtP equals $v \mathrm{P}$ in terms of lexical syntactic category. The fact that it is in a scope position is reflected by the scopal non-ambiguity of the example. ${ }^{3}$ There is an alternative analysis by which the particle undergoes merger with the DP. The result is what I call a SMALL PARTICLE PHRASE (SPrtP).

(2) a. We are required to study only SYNTAX

b. We are required to [ ${ }_{\mathrm{vP}}$ study [SPrtP only [DP SYNTAX]]]

A classical finding about examples of type (2) is that they can be ambiguous (see Klima 1964 on negation, and Taglicht 1984 and Rooth 1985, 1992 on FPs.) The point is that unlike in (1), the particle is not in a proper scope position. A traditional answer would be that it undergoes LF-movement to a scope position which can be the lower $v \mathrm{P}$ or - as a more marked case - the next higher $v \mathrm{P}$ while nothing of this sort happens in (1) due to the fact that the particle is already frozen in a proper scope position.

Notorious German examples with a SPrtP in first position as seen in (3)

(3) Nur Florenz haben die Touristen besucht

only Florence have the tourists visited

'It was only Florence that the tourists visited'

\footnotetext{
3 Apart from this, only may quantify over properties (e.g. study syntax) or over individuals (e.g. syntax). Due to nuclear stress, this difference is phonetically undetermined. For reasons of space, I limit myself to $v \mathrm{P}$ and leave out the bigger generalization according to which some focused $\mathrm{XP}$ may also qualify if it is the predicate of a proposition as in small clauses. See Grohmann and Kallulli (2006), Frascarelli (2010), and for earlier discussions with respect to FPs Jacobs (1983) and Bayer (1996).
} 
are no problem in this theory. The particle is not interpreted where it occurs phonetically but lower down in the clause. The first constituent is the SPrtP [nur FLORENZ]. ${ }^{4}$ This phrase is initially merged in $v \mathrm{P}$ as the direct object of visit. From there it moves to the specifier of a silent Prt-head which heads the regular PrtP associated with $v$ P. This is the position where the particle finds its scope position. Spec-head agreement (SHA) with the particle head freezes its scope. The rest of the derivation affects the particle on the PF-side of the grammar but not on the LF-side. The topicalization we see in (3) has no effect on the semantic scope of the particle. The steps are summarized in (4); the scope of the particle is indicated with $\checkmark$

(4) a. [ ${ }_{v \mathrm{P}}$ die Touristen [ ${ }_{\mathrm{VP}}[\mathrm{SPrtP}$ nur FLORENZ] besucht]] = MERGE Prt =>

b. [Prt' $\operatorname{Prt}\left[_{v \mathrm{P}}\right.$ die Touristen [vP [SPrtP nur FLORENZ] besucht]]]

$=$ MOVE SPrtP \& SPECHEAD AGREEMENT $=>$

c. [PrtP [SPrtP nur FLORENZ] [ $\mathrm{Prt}^{\mathrm{Prt}} \checkmark$ [ ${ }_{\mathrm{v}} \mathrm{P}$ die Touristen[vp fsPrtP Aur FLORENZ] besucht]]]]] $\longleftarrow$ SHA

$=$ further steps $=>$

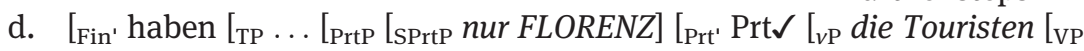
[SPrtP Aur FLO-RENZ] besucht]]]]]]]

$$
=\text { MOVE SPrtP }=>
$$

e. [FinP [SPrtP nur FLORENZ] [Fin' haben [ TP $_{\text {Tie }}$ Touristen [PrtP SSPrtP $_{\text {nur }}$ FLORENZ] [Prt' Prt $\checkmark$ [vP die Touristen [vp [sPrtP nur FLORENZ] besucht]]]]]]]

As one can see, raising of the SPrtP to the immediate pre- $v \mathrm{P}$ position derives a semantically interpretable structure in which the Prt-feature on the SPrtP is interpretable and ceases to be syntactically active. We express this in terms of SHA à la Rizzi (1991/1996). ${ }^{5}$ The second raising of this phrase that we see in the transition from (4d) to (4e) has no relevance for the particle. The particle is simply pied-piped along. ${ }^{6}$

4 Since the particle does not impose a syntactic category, the phrase structure of the SPrtP looks like an adjunction construction: [DP nur [DP Florenz]]. For the sake of readability, this structure will remain implicit in the following.

5 Barbiers (2010: 26), who shares with me and others the basic difference between the particle's scope and its associated focus, makes a very similar proposal by which a NumP prefixed with a particle raises to the specifier of a particle that is prefixed to TP or VP. The latter position defines the scope domain. Referring to Haegeman (1995), he proposes SHA as the mechanism that "fuses" the two occurrences of the particle syntactically.

6 Approaches to FPs in which the FP can freely team up with non-propositional XPs and nevertheless find its way to propositional scope have been suggested by Barbiers (2014) and by Smeets and Wagner (2017). 
Assume next that the grammar of DiPs works more or less in the same way. We assume that a DiP is merged with $v \mathrm{P}$ (or an "extension" of it, for example a NegP). In this case, the DiP is in an irreversible scope position. The question is then how the DiP can be made dependent on the clause type and ultimately on the speech act type of the sentence. As argued extensively in Bayer and Obenauer (2011) and in Bayer, Häussler and Bader (2016), the DiP does not undergo LF-movement to the left periphery; it rather enters a probe-goal agreement relation with whatever represents the clause type and ultimately the speech act in the upper left periphery. Since the DiP is merged in a proper scope position, there is no need for it to move away. This explains why in the core cases we do not find displacement of DiPs.

Unlike FPs, DiPs do not seem to enter alternative constituentships. ${ }^{7}$ There is at least one exception though: In wh-interrogatives, DiPs can team up with a wh-phrase. In German, a somewhat marked but fully legitimate and in fact rather frequent alternative to $(5 a)$ could be (5b). ${ }^{8}$
a. An wen könnte er sich denn gewandt haben?
at who could he REF DENN turned have
'Who could he have turned to after all?'
b. An wen denn könnte er sich gewandt haben? At who DENN could he REF turned have

The interpretation of (5b) is almost the same as in (5a), the difference being that (5b) is a more emotionally loaded, more emphatic question with a more exclamative flavor. The construction has been studied in Meibauer (1994), Bayer and Obenauer (2011) and then in Bayer and Trotzke (2015) and more recently in Bayer (2018). Trotzke and Turco (2015) as well as Trotzke (2017) provide experimental evidence that the wh-phrase in (5b) has a specific phonetic signature that could be identified as a typical property of emphatic speech. The syntactic assumption is that the DiP may undergo merger with a wh-phrase forming again a SPrtP, [SPrtP Prt whP]; this whP moves to the specifier of the SPrtP where it values a feature for emphasis that the DiP has been endowed with in the

\footnotetext{
7 A plausible reason for this could be that DiPs do not associate with a focus-bearing constituent in the way FPs do. DiPs separate the topic domain from the (information) focus domain but they do not induce focus alternatives.

8 The DiP denn (lit. then) is restricted to interrogatives and imports a quasi anaphoric relation to the discourse in which the question is uttered. Denn means something like "after all", "under the actual circumstances".
} 
numeration. The result of this operation is [SPrtP whP [Prt whP]]. ${ }^{9}$ The unavoidable conclusion is that wh and DiP can form a constituent, and that this constituent undergoes wh-movement, pied-piping the DiP along just like in the case of the FPs we considered above. As shown by the works quoted above, there is strong evidence that in this case the DiP is not interpreted where we see it but rather in the place of the copy that the SPrtP has left behind in the specifier of the particle phrase that is already familiar from our discussion of the syntax of FPs. An immediate idea could be that the DiP is merged with $v \mathrm{P}$ and is then picked up by the wh-phrase once it moves out of $v \mathrm{P}$.

(6) a. ... [PrtP Prt $\left.\left.\left[{ }_{v \mathrm{P}} \ldots w h \mathrm{P} \ldots\right]\right]\right]=>$

b. ... [PrtP $[\mathrm{Prt} w h \mathrm{P}]\left[{ }_{v \mathrm{P}} \ldots\right.$... $\left.\left.]\right]\right] \Rightarrow$

c. ... [PrtP $[\operatorname{sPrtP} w h \mathrm{P}[\operatorname{Prt} w h \mathrm{P}]][v \mathrm{P} \ldots \mathrm{wP} \ldots]]] \Rightarrow$

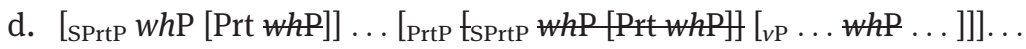

However, this is not a viable solution. As pointed out in Bayer and Trotzke (2015), the step from (6a) to (6b) violates the Extension Condition, see Chomsky (1995: 248), which requires that "Merge always applies at the simplest possible form: at the root". Notice also that the on-line formation of a SPrtP would prevent the whP from c-commanding its trace/copy in $v \mathrm{P}$. The alternative is to generate the SPrtP in a separate work space and merge it in $v \mathrm{P}^{10}$ In this case, the derivation works along the lines of (4): on its way out of $v \mathrm{P}$, the SPrtP cycles through the specifier of a particle phrase that has been created by merger of a silent particle, and in which it undergoes SHA. Let us see in (7) how the derivation of example (5b) proceeds; once again, the scope of the particle is indicated with $\checkmark$.

(7) a. [ ${ }_{v \mathrm{P}}$ er [VP sich [SPrtP an wen denn an wen] gewandt haben könnte]]

$$
\text { = MERGE Prt }=>
$$

b. [Prt' $\operatorname{Prt}{ }_{{ }_{\nu \mathrm{P}}}$ er [ ${ }_{\mathrm{VP}}$ sich [SPrtP an wen denn an wen] gewandt haben könnte]]]

$=$ MOVE SPrtP \& SPECHEAD AGREEMENT $=>$

c. $\quad\left[\operatorname{PrtP}[\operatorname{sPrtP}\right.$ an wen denn $]\left[\mathrm{Prt}^{\prime} \operatorname{Prt} \checkmark\left[{ }_{\mathrm{v} \mathrm{P}}\right.\right.$ er $[\mathrm{vp}$ sich $\mathrm{fSPrtP}$ an wen denn] gewandt - SHA haben könnte]]]]

$=$ further steps $=>$

d. [Fin' könnte $\left[_{\mathrm{TP}}\right.$ er sich ... [ [PrtP [SPrtP an wen denn] [Prt' Prt $\checkmark\left[{ }_{v \mathrm{P}}\right.$ ex [ ${ }_{\mathrm{VP}}$ sich [SPrtP an wen denn] gewandt haben]]]]]] $\quad=$ MOVE SPrtP $=>$

9 The simplest assumption about [SPrtP whP [Prt for emphasis, and that an emphatically marked whP moves into its specified where it agrees and deletes this uninterpretable feature. For further details see Bayer and Trotzke (2015).

10 The inner structure of theSPrtP is as in [SPrtP [an wen] [SPrt denn [an this structure in the following derivation for reasons of readability. 
e. [FinP [SPrtP an wen denn] [Fin' könnte $\left[_{\text {TP }}\right.$ er sich ... [ [PrtP tsPrtP wen denn] [Prt' Prt $\checkmark\left[{ }_{v \mathrm{P}}\right.$ er [VP sich $\mathrm{LSPrtP}_{\mathrm{V}}$ wen denn] gewandt haben]]]]]]]

The step from (7b) to (7c) freezes the scope of denn by SHA, and denn is deactivated. The raising of the SPrtP we see in the transition from (7d) to (7e) is nothing else but regular wh-movement by which denn is pied-piped along, a movement step that has no relevance for the semantic interpretation of denn.

This derivation is technically feasible and serves as input to further processes of agreement between the DiP and the higher left periphery's features of clause type and speech act. These are not relevant in the present context; interested readers are referred to Bayer, Häussler and Bader (2016) and to my previous work on this issue. The advantage of the account is obvious: (i) it rests on processes which are known from the paradigm case of wh-movement or the syntax of negation. (ii) it unifies the syntax of FPs and DiPs to a maximal degree, a result that is conceptually desirable. The account depends crucially on the assumption that DiPs as well as FPs are functional heads. Standard adjunction does not create the positions into which a SPrP moves, and the formation of a SPrP itself is hard to imagine if the particle is an adjunct. Thus, we have a strong argument in favor of the "head theory" and against the "adverb theory". There is one point though which might be seen as a technical trick to get the derivation running. This is the merger of a silent particle. In the rest of this chapter, I want to comment on this point with novel data.

\section{Doubling discourse particles}

It is known from the work of Thurmair (1989) and following work that in German DiPs can be stacked. It is less known that they can also be doubled ${ }^{11}$. Consider the following example in (8).

(8) Vor was denn ist er denn geflüchtet? from what DENN is he DENN fled

'What on earth did he flee from?'

http://www.trennungsschmerzen.de/verlassen-mit-baby-wer-noch-t604. html (24.01.2016)

11 This section has benefitted in particular from comments by Michael Wagner. 
The repetition of the particle denn could in principle be a speech error which by some accident made it onto a web page. This would in a sense trivialize the example. But it is unlikely that this would count as an explanation. Examples like those in (9), in which another constituent is doubled, appear to be rare if not inexistent. \# should signal an uncertain deviation from the standard.

(9) a. \#Vielleicht ist er vielleicht ins Kino gegangen

perhaps is he perhaps in.the movie gone

'Perhaps he went to the movies'

b. \#Gerade sind sie gerade nach hause gekommen just are they just to home come

'They just came home.'

c. \#Er ist er vielleicht ins Kino gegangen he is he perhaps in.the movie gone 'Perhaps he went to the movies'

d. \#Was für Leuten passiert für Leuten so etwas what for people happens for people so something 'What kind of people does something like that happen to?'

(9a,b) show that regular adverbs are unlikely to be echoed. (9c) shows that pronouns, i.e. comparably short and unstressed element, are unlikely to be echoed. (9d) shows that phrases which are attached to wh-words are equally unlikely to be echoed. In addition, if some part of speech is repeated as a result of lack of processing capacities, the distance between the two occurrences would hardly be as close as the distance between the occurrences of denn in (8). (10a) shows a frequently observed blending in running speech, but (10b) sounds unrealistic because the distance between the doubled parts is extremely small.

(10) a. Der ist doch schon vor zwei Jahren für einen Monat he is DOCH already before two years for one month in Florenz gewesen ist der

in Florence been is he

Literally: 'He has been in Florence for one month already two years ago, don't you rember?'

Suggestive question: 'Hasn't he already been in Florence for one month two years ago?'

b. \#Der ist hier ist der

he is here is he

'He is here.' 
According to these considerations, an explanation of (8) in terms of speech errors or processing overload appears to be inadequate. Importantly, the example seen in (8) is not an isolated case. The examples that follow in (11) through (14) are a collection of internet finds on the doubling of different DiPs which can cooccur with whP in SPrtPs. ${ }^{12}$ The numbers in square brackets refer to the sources listed in the appendix.

(11) Examples with denn

a. Wer denn hat denn merkel gewählt??? [1]

'Who has voted for Merkel after all?'

b. Hab das jetzt schon öfters gelesen, dass eben nicht Brecko den Wagen gefahren haben soll, aber wer denn hat denn nun hinter dem Steuer gesessen? [2]

'I've read this a couple of times that Brecko did not drive the car but who on earth was behind the stirring wheel then?'

c. Wer denn hat denn noch Interesse [3]

'Who is still interested after all?'

d. Wer denn will denn nach Berlin? [4]

'Who wants to go/move to Berlin after all?'

e. Wie denn ist denn der Kontakt zu den Reutlinger Banater Schwaben zustande gekommen? [5]

'How then did the contact with the Reutlingen Banat Swabians come about?'

f. Wie denn wäre er denn ,vorgegangen“ gegen den Lehrer, der den Islam nicht nach Weisung der Moslems darstellt? [6]

'How would he have "acted" then against the teacher who did not represent islam according to the rules of the muslims?'

g. Wie denn könnten wir denn besser unsere Einheit im Grund, der gelegt ist in Christus, bekunden? [7]

'How then could we better express our unity on the foundation that is defined by Christ?’

12 I am indebted to Verena Simmler, who compiled this list of examples. For reasons of space, the examples are not glossed but simply translated in an intuitive way to the extent that a halfway realistic translation is possible. Orthography largely retains the original form. What is relevant is the structure. I provide the entire collection as it will become relevant when we discuss their underlying structure. References to work on the particles denn, nur, schon and wohl can be found in Bayer and Obenauer (2011) and in various other publications. 
h. Wie denn könnten denn unsere Politiker solche Firmen ertragen, weiter Waffen verkaufen, wenn sie nicht die Gabe des „weisen Marabu“ hätten? [8] 'How after all could our politicians tolerate such companies (and?) continue to sell weapons, if they did not have the gift of the "wise maraboo"?'

i. Wie denn sollten sie denn auch gehandhabt werden? [9] 'How should they be handled then?'

j. Vor was denn ist er denn geflüchtet? [10] = (8)

'What on earth did he flee from?'

k. Bitte erleuchten Sie mich, was denn sind denn die Pyramiden und auf welchen Forschungen beziehen Sie ihr Wissen? [11]

'Please enlighten me, what are the pyramids after all, and from which research do you derive your knowledge?'

1. Was denn sind denn deine Favoriten? [12]

'What are your favorites then?'

m. Nun mal Butter bei de Fische, was denn sind denn diese Spiele? [13]

'Don't try to evade my question, what are these games really?'

n. Vor allem, was denn hätte denn Schlimmeres passieren können? [14] 'Above all, how could things get worse after all?'

o. Oh, wo denn ist denn nochmal der Frosch hin? [15] 'Oh, where again did the frog disappear then?'

p. Wo denn ist denn hier nur dieser komische empfehlen-knopf. . .? [16] 'Where after all is this funny recommendation button?'

q. Und wo denn sind denn all Eure Rechtsantworten auf eingereichte Strafanzeigen von mir, Herrn Moritz Günthert, meinen Mandanten oder meinen behandelten Ärzten geblieben? [17]

'And where please have all your juridical responses to declarations been left that have been filed by myself, Mr. Moritz Günthert, my clients or my doctors?'

r. Seit wann denn ist denn das thema Sex für u18 nicht erlaubt? [18] 'Since when is the topic "Sex" not allowed for those under 18?'

s. Seit wann, Schrammel, seit wann denn hast du denn 'nen Krankenschein? [19]

'Since when, Schrammel, since when do you have a sick report?'

t. Warum denn hat denn die Fee den Drachen nicht gestreichelt. . .? [20] 'Why after all did the fairy not caress the dragon?'

u. Warum denn sollte ich denn was von dir behalten? [21] 'Why on earth should I keep stuff that belongs to you?'

v. Warum denn sollte ich denn in einen Wert engagiert sein, wenn ich ihn erwähne? [22]

'Why after all should I be engaged in a value that I do not mention?' 
w. Vom wem denn bin ich denn der beste Freund, ...? [23]

'Whose best friend am I after all?'

x. Wen denn hast du denn alles so lieb? [24]

'Who all are dear to you then?'

(12) Examples with nur

a. Wer nur könnte nur hinter den ausgeklügelten Überfällen stecken? [25]

'Who on earth could be responsible for these sophisticated attacks?'

b. Was nur ist nur mit denen los? [26]

'What the hell is going on with them?'

c. Warum nur bin ich nur so langsam? [27]

'Why the hell am I so slow?'

d. Warum nur bin ich nur so spät hier? [28]

'Why the hell am I here at this late hour?'

e. Warum nur bist Du nur gegangen? [29]

'Why on earth did you leave?'

f. Warum nur bist du nur so scharf drauf das Saugrohr zu wechseln? [30] 'Why the hell are you so keen to change the suction-pipe?'

g. Warum nur ist er nur so schweigsam? [31]

'Why on earth is he so reserved?'

h. Warum nur seid ihr nur so wie ihr seid? [32]

'Why on earth are you as you are?'

i. Warum nur seid ihr nur soo gehässig? [33]

'Why the hell are you so malicious?'

j. Aber warum nur sind nur so viele Familienbande, Freundschaften der Deutschen nach Jahren der zwangsweisen Trennung und des Zusammenhaltes, auch einer Solidarität über das berühmte Westpaket, einfach so zerbrochen??? [34]

'But why on earth did so many family ties and German friendships break apart just like this after years of forced separation and unity, also solidarity concerning the celebrated parcel from the west?'

$\mathrm{k}$. Warum nur war ich nur immer so schrecklich unkreativ? [35]

'Why the hell was I always so terribly un-creative?'

1. Warum nur war er nur nicht schneller da gewesen? [36]

'Why the hell did he not show up earlier?'

m. Warum nur war er nur so unerreichbar für mich? [37]

'Why on earth was he so unreachable for me?'

n. Warum nur habe ich nur das Gefühl, Sie hätten absolut keine Ahnung wie der Wissenschaftsbetrieb funktioniert. . . [38] 
'Why on earth do I have the feeling that you have absolutely no idea how the science business works?'

o. Warum nur haben wir nur trotzdem immer das Gefühl, als Schnorchler von Tauchern immer so von oben herab behandelt zu werden? [39]

'Why on earth do we as snorkelers nevertheless always have the feeling to be treated by divers in a condescending manner?'

p. Warum nur habt ihr nur Merkel gewählt? [40]

'Why the hell did you vote for Merkel?'

q. ...warum nur habt ihr nur zugelassen, dass sich Ville bis zum Leberversagen betrinkt? [41]

'Why the hell did you permit Ville to drink his liver away?'

r. Warum nur haben Sie nur solange gewartet auf die Antwort der Menschlichkeit! [42]

'Why on earth did you wait so long for an answer of humanity!'

s. Aber warum nur hattest du nur diesen komischen Gesichtsausdruck? [43] 'But why the hell did you have this funny expression?'

t. Warum nur hatte sie nur diese Empfindungen? [44]

'Why on earth does she have these sensations?'

u. Warum nur können nur manche Leute den Tod nicht akzeptieren? [45] 'Why on earth can certain people not accept death?'

v. Warum nur musste ich nur laut lachen als ich las wer die Leitung übernimmt. [46]

'Why the hell did I have to laugh loudly when a read who takes over the leadership.'

w. Warum nur musstest Du nur zu Ihr gehen?! [47]

'Why the hell do you have to go to her?!'

$\mathrm{x}$. Warum nur musstest du nur mein Leid ertragen? [48]

'Why on earth did you have to suffer my pain?'

y. Warum nur musste er nur so rennen? [49]

'Why the hell did he have to run so fast?'

z. Warum nur musste nur jedes rothaarige Mädchen Kimberly Ane heißen? [50]

'Why on earth had every red-haired girl to be named Kimberly Ane?'

The particle nur can be used both as a DiP and as an FP. It is important to notice that in some of the examples the FP reading is excluded for principled reasons. This is, for instance, the case in (120). Provided that the FP nur cannot associate with the non-contastable element trotzdem ("however"), the assertive version *Gerlinde und Rosa haben nur trotzdem immer das Gefühl,... ("G. and R. have only however always the feeling ..." is predicted to be 
impossible. Therefore, the lower nur in (120) can only be a DiP. However, all of the examples are naturally interpreted with all occurrences of nur as DiPs. This suggests that we are really dealing with the doubling of the DiP and not with a mix of DiP and FP.

(13) Example with schon

Auch von Tissie Andere erfuhr er nichts, denn wer schon hätte schon Lust gehabt, seine Freunde zu verpfeifen. [51]

'Also from Tissie Andere he didn't learn anything because who would have liked to betray his friends [certainly nobody].'

(14) Examples with wohl

a. Wer wohl ist wohl der Typ mit dem Doppelkinn, und der spärlichen Frisur. [54]

'Who is the guy with the double chin and the scanty hair style, I'm wondering.'

b. Und wer wohl hat wohl am meisten von diesem Produktionszuwachs profitiert? [55]

'Guess who has profitted the most from this increase in production.'

c. Warum wohl ist er wohl Mitglied bei „BT-go“? [56]

'Why, you may ask, is he a member of "BT-go"?'

d. Warum wohl sind sie wohl gelöscht worden? [57]

'Why, I'm wondering, have they been deleted?'

e. Warum wohl ist wohl in dem anderen Auto niemand gestorben? [58]

'Why, I'm wondering, did nobody die in the other car?'

f. Und warum wohl ist wohl die Kundeninfo von YEG (. . .) nicht mehr direkt auf der Homepage von Heino verlinkt? [59]

'And why, tell me, is the customers' information not any longer linked to Heino's homepage?'

g. Warum wohl sind wohl die Kandidaten bei GNTM, am Ende dann KEINE Topmodels ...? [60]

'Guess why the candidates at GNTM are no top models in the end.'

h. Warum wohl waren wohl GULAGs notwendig? [61]

'Why were GULAGs necessary after all?'

i. Warum wohl habe ich wohl nach den Aufbau der bestehenden Steuerung gefragt ...? [62]

'Guess why I asked about the set-up of the existing control.'

j. Warum wohl habe ich wohl 3 Shure M 91 mit DN 330 genommen? [63]

'Guess why I took 3 Shure M 91 with DN 330.' 
k. Warum wohl haben wir wohl in der Quali erst gegen Tschechien gewonnen und dann verloren? [64]

'Why, do you think, did we first win and then lose in the qualification against the Czech Republic?'

1. Warum wohl hat wohl das deutsche Verkehrsministerium von all dem nichts gewusst? [65]

'Why did the German Ministry of Transport not know about all of this?'

m. Warum wohl hat wohl Horst Seehofer im Interview gesagt, dass „die, die tatsächlich entscheiden, nicht gewählt sind und die, die gewählt sind, nichts zu entscheiden haben"? [66]

'Why, for heaven's sake, did Horst Seehofer say in the interview that those who decide are not elected and those who are elected have nothing to decide?'

n. Warum wohl haben wohl auch die regierungskritiker den kopf geschüttelt. [67]

'Why, do you think, even the government critics shook their head?'

o. Warum wohl haben wohl gute Ladegeräte und auch der viel zitierte Stirling-Regler eine Anschlußmöglichkeit für einen Temp.-Fühler? [68] 'Why after all do solid chargers and also the much-mentioned Stirling regulator have a connection option for a temp.sensor?'

p. Warum wohl könnte ich wohl Firefox 1.0 x erwähnen wollen? [69] 'Why for heaven's sake could I be inclined to mention Firefox 1.0 x?'

q. Und warum wohl sollte ich wohl das deutsche youtube bemuehen? [70] 'And why, do you think, should I rely on the German youtube?'

r. Warum wohl sollten sie wohl Waffen in den Händen halten, wenn sie sie nicht benutzen? [71]

'Why on earth should they hold weapons in their hands if they don't use them?'

s. Warum wohl sollten sie wohl die Zahlen zurückhalten, wenn die gut wären? [72]

'Why after all should they withhold the numbers if they were ok?'

t. Warum wohl sollte wohl beispielsweise ein Ochs grade bis 2010 verlängern, der wohl zweifelsfrei den Anspruch haben dürfte, um etwas mehr als den Klassenerhalt zu spielen? [73]

'Why, for example, should an Ochs prolong his contract exactly until 2010 given that he is undoubtedly ready to play for more than just class maintenance?'

u. Warum wohl hat wohl niemand in Deiner Aussage das Erkennen und schon gar nicht das Verwenden von irgendwas erkannt? [74] 
'Why, for heaven's sake, did nobody recognize in your statement the perception, let alone the use of something?'

v. Warum wohl sollten wohl die Eltern ihren Kindern das mit dem Sex beibringen, hm? [75]

'Why should, do you think, parents teach their children about sex, huh?'

Within the theory that has been sketched so far, there is a straightforward explanation for the doubling of DiPs. Reconsider the derivation of the question An wen denn könnte er sich gewandt haben? in (7). The doubling construction is already there. After the SPrtP an wen denn had been merged in $\mathrm{VP} / v \mathrm{P}$, a silent Prt-head was merged with $v \mathrm{P}$, and the SPrtP was attracted to its specifier. The only change we need to assume now is that instead of a silent particle an OVERT particle is merged. Since there is Spec-Head agreement, the overt particle and the Prt-head of the SPrtP have to match, i.e. the Prt-head and the head of the SPrtP must be identical. This is the case. For the rest, the derivation remains the same as the one we have seen in (7). The result of (7), namely (7e), is then as in (15). ${ }^{13}$

(15) $\left[_{\text {FinP }}\left[\mathrm{SPrtP}\right.\right.$ an wen denn] [Fin' könnte $\left[_{\mathrm{TP}}\right.$ er sich ... [PrtP [SPrtP wen denn] [Prt' [Prt denn] $\checkmark$

[ $\mathrm{P}$ er [vp sich [sPrtP an wen denn] gewandt haben]]]]]]]

The lower denn is the DiP which determines the scope and is thus the semantically relevant one. The denn in the SPrtP has an extra feature for emphasis by which the wh-phrase moves to its left. If so, there is no redundancy. The two lexical occurrences of the DiP are the reflex of spelling out the lower head position. It is a matter of PF.

This looks like an attractive solution, and I will, in fact, stay with it. Nevertheless, there is a slight complication. The question is: can we exclude the possibility that the preposed SPrtP reconstructs into another potential particle projection, one that is independent of the spelled-out DiP? Since we can be sure that the preposed SPrtP cannot be interpreted in the high position where we see it in the output, the question is whether there can be particle doubling also in the middle field. The answer depends on data, of course. We know that different DiPs can line up in German, see Thurmair (1989) and Coniglio (2011). But are there also data in which the same particle recurs? We know that the same particle can recur if one is a FP and the other one is a DiP.

13 Prosodically, the example shows two peaks, one which results from the emphatic accent on the whP, the other, on the verb gewandt, obviously from the lower DiP which has a focusing function although it is not a FP. For an interesting approach to capture the relation between DiP and focus see Egg and Mursell (2017). 
(16) Wer hat schon schon überlegt ob er/sie in who has SCHON SCHON considered whether he/she in Ketose ist [76] ketosis is

'Who after all has already thought about whether he/she is in the fat burning mode? - Nobody!'

Here, the first schon is the DiP that gives rise to the interpretation as a rhetorical question; the implicature is that, in fact, nobody has deliberated whether $\mathrm{p}$ is the case. The second one is a scalar FP which corresponds to the temporal operator "already". The question is whether identical DiPs can recur which allow no ambiguity with respect to their FP/DiP status. To be sure, we need to look for recursion of denn and wohl, both of which cannot be FPs. There are indeed such examples.

(17) a. Wer sind denn denn die „gegen Toleranz wetternden who are DENN DENN the against tolerance raving Kreise"? [77]

circles

'Who are those circles raving against tolerance?'

b. Wer hat Euch denn das denn bitte empfohlen? [78]

who has you.PL DENN this DENN please suggested

'Who has, pardon me, suggested this?'

(18) Und warum hat der Bundestag wohl den Stgb

and why has the parliament WOHL the penal.code

$\$ 129$ wohl so formuliert [79]

$\S 129$ WOHL so formulated

'And why has the German parliament formulated $§ 129$ if the penal code in such a way?'

These examples show that it is in principle possible that the very same DiP recurs. If we can exclude speech errors, there should be a difference. Nevertheless, it is difficult to tell the difference between the two positions. Intuitively, it looks as if the first occurrence is the more general one which reshapes or modifies the illocutionary force whereas the second is in the service of information structure and interacts with the focus inside the predicate. At this moment, this is pure speculation; thus, I leave the issue pending. For the question of doubling, the conclusion must be that reconstruction of the SPrtP into the specifier of a PrtP whose DiP is spelled out is not the only analysis. 
The SPrtP we see in (14) could in principle have cycled through a SEPARATE projection where its DiP-head agrees with the empty particle of a particle phrase that is independent of the spelled out DiP.

There is a reason why a reduction of the examples we see in (11) through (14) to this explanation seems problematic. Notice that the in-situ doubling cases are usually like in (19)

\section{(19) Wer hat nur diesen linksrotgrünfaschistischen Idioten nur so viel who has NUR these left.red.green.fascist idiots NUR so much Macht verliehen, dass die ihre geisteskranken Visionen in given given that they their mind.sick visions in die Tat umsetzen können? [80] the deed transform can 'Who on earth gave these leftist red and green fascist idiots so much power that they can turn their sick visions into reality?'}

There is a high DiP which follows the finite verb and a low DiP near $v \mathrm{P}$ which is preceded by given information. Taking the option of multiple in-situ occurrences of the same DiP as a basis, consider now again movement of the SPrtP out of $v \mathrm{P}$. The SPrtP would agree and take scope in the lowest criterial position before it moves on to the wh-destination. Skipping the low position followed by agreeing and scoping in the high position cannot arise as it would violate Relativized Minimality, see Rizzi $1990 .^{14}$ Turning now to the collection of data in (11) through (14), we see, however, that the spelled-out DiP in situ is always in a rather high position. In roughly $50 \%$, it follows the finite verb directly; in the other $50 \%$, it is separated from the finite verb only by a

14 Yvonne Viesel (p.c.) notes this reasoning is not fully conclusive. The multiple DiPs could in principle differ from each other in their respective function, say, by virtue of their information structural role. If the SPrtP reflects these differences, it could be primed to skip the low position because this low position would be featurally incompatible with the features of the SPrtP. Unfortunately, I have no idea how to test this and will therefore leave it as an unresolved problem. In connection with (15), we suggested that the DiP of a SPrtP has an extra feature for emphasis by which the wh-phrase moves to its left. As Bayer and Trotzke (2015: §3.3) point out, the feature for emphasis is likely to be checked in the upper left periphery. SPrtPs in lower position appear to be awkward. This is reminiscent of findings about the-hell questions in English, see Pesetsky (1987) and den Dikken and Giannakidou (2002). If so, the SPrtP is not a featural unity, and its Prt and its Emp-feature will be checked in distinct functional positions. No conflict with Relativized Minimality can arise. 
pronoun. ${ }^{15}$ In the face of this, movement of the SPrtP through a low specifier position with a silent Prt-head is - at least quantitatively - not supported by the data.

The derivation that converges immediately is the one that has been proposed in (15). In (15), doubling arises by means of an SPrtP that passes through a single criterial position whose head is spelled out with the same DiP that heads the SPrtP. In the face of this, my conclusion is for the time being that DiP doubling as seen in (11) through (14) should not be reduced to agreement in Prt-projections with a SILENT head. It is rather agreement in Prt-projections with an OVERT head. If my conclusion is on the right track, the doubling data lend new support to my theory as it has been developed in my previous publications.

\section{A note on focus particle doubling}

It is widely known that focus particles (FP) can be doubled in the sense of double acts of quantification.

\section{(20) Only John ate only vegetables}

There are two distinct onlys, and the reading is that for nobody else than for John it was true that he ate nothing else but vegetables. From (20) it follows that people other than John ate - perhaps in addition to vegetables - also fish or meat or pasta or bread. This is not surprising. We are all familiar with stacked negation as in Nobody ate no vegetables at all, which amounts to 'Everybody ate at least some vegetables'.

In rarer cases, one can, however, also find examples in which logical cancellation is unlikely. Consider the following internet finds:

(21) a. they are solid options for the wireless speaker fan, even if they only support only the original AirPlay. [81]

15 As long as the pronoun does not bear contrastive stress, this ordering is exceptionless. The fact that no examples were found with the in-situ DiP in a lower position is surprising. According to my intuitions, examples like (i) still sound quite natural.

(i) Warum denn bist du gestern

why DENN did you yesterday

denn nicht gekommen?

DENN not come

'Why the hell didn't you come yesterday?' 
b. the stakes have never been higher as he only has only 48 hours to find someone to take care of his young daughter [82]

c. He doesn't love me at all; he only thinks only of himself. [83]

These examples come across like a blend of (1a) and (2a). The pre-VP only is in an irreversible scope position whereas the lower only is the one that needs to raise to the scope position or needs to be probed from the scope position. In the context of my account of DiP doubling, these data receive a straightforward explanation: There is a SPrP in situ, headed by only, and there is a pre-verbal PrtP with a spelled-out head only. Unlike in (20), the two particles are two ocurrences of the same operator. The two phonetic occurrences are linked by an agreement relation. Semantically, there is only a single occurrence of only. (21c) means the same as "He only thinks of himself" with (of) himself being the focus associate. FP-doubling seems to rest on the same mechanism as negative concord. This can be seen in the standard Italian example non ho visto nessuno, in which non occupies the scope position and nessuno is according to my theory a "small negation phrase" (SnegP).

To return to the continental Germanic side, Barbiers (2010, 2014) observes doubling of FPs in colloquial Dutch, especially with the FP maar ('only'). Consider (22).

\section{(22) Maar een student ken ik maar \\ MAAR one student know I MAAR \\ 'I know only one student.'}

The preferred reading of (22) seems to be that of all numbers of students I know, this number is exhausted by one. One could imagine also another reading by which there are two maars involved. Of all persons I know, this set of persons is exhausted by not more than a single student. There would be one maar base-generated in pre- $v \mathrm{P}$ scope position, and a second maar in the DP, the scope of which would be confined to the scale of natural numbers excluding those that go beyond 1. This meaning is hard to compute, and it is clearly not how the Dutch speaking majority would understand (22). According to my reasoning so far, the structure of (22), before V2 and movement to SpecCP, would be as in (23).
(23) ... ik [PrtP [SPrtP maar een student] [Prt' maar ${ }_{{ }_{v \mathrm{P}}} i k \mathrm{kSPrtP}$ mareen student] ken]]]

Strangely, finding convincing examples of FP doubling turns out to be hard in German. The closest I could find in a cursory search was (24). 
(24) Die Verlage haben nie etwas beanstandet, nur the publishing.houses have never something criticized only einer hat mich nur einmal ganz ganz höflich auf meine one has me only once very very politely to my Flüchtigkeitsfehler aufmerksam gemacht ... [84] careless.mistakes attentive made ... 'The publishers never criticized anything. Only one of them, very politely, once drew my attention to my slips of the pen ...'

Here, one cannot exclude a reading with two distinct representations of nur. Nevertheless, it seems to be easy enough to understand (24) with only a single interpretation of nur as in ... nur einer hat mich einmal ganz ganz höflich auf meine Flüchtigkeitsfehler aufmerksam gemacht or ... einer hat mich nur einmal ganz ganz höflich auf meine Flüchtigkeitsfehler aufmerksam gemacht.

This brief digression into the realm of only/maar/nur FPs can clearly not do justice to the theoretical complexities of FP-constructions. It could show, however, that my account of doubling DiPs may stand a good chance of being extendable to the domain of FPs. Given there is a silent head in scope position and an overt head in a SPrtP, it is not unreasonable to expect that the silent head may occasionally be spelled out.

\section{Conclusions}

The syntax of focus particles as well as the syntax of discourse particles in German allows a much more unified account than has been possible so far if certain well motivated assumptions are adopted. These assumptions include i. that particles are functional heads, ii. that they not only merged into scope positions but may also be co-constituents of non-propositional phrases such as PP and DP. iii. Phrases of the latter kind - "Small Particle Phrases" - must cycle through designated positions in which they can discharge their scope potential via agreement. iv. The derivation calls for spec-head agreement configurations in combination with the copy-theory of movement. v. While in the standard cases, they agree with a silent matching head, we have presented new data which show that this head can also be spelled out. Both the data and the theoretical account give support to theories in which particles, focus as well as discourse particles, are functional heads along with standard functional heads that are assumed in the grammar of German and many other languages. If focus particles and discourse particles are adverbs and therefore purely lexical 
XPs, as the majority of researchers assume to date, it is impossible to arrive at the generalizations that are now in reach.

\section{Appendix}

\section{Sources of internet data and time of finding in parentheses}

[1] https://propagandaschau.wordpress.com/2015/05/13/wdr-verbreitet-erneut-aus-demkanzleramt-finanzierte-pr/ (23.01.2016)

[2] http://forum.express.de/showthread.php?t=17396\&page $=57(23.01 .2016)$

[3] http://de.comp.os.unix.apps.kde.narkive.com/Jd9YV1b5/deutsche-anleitung-zu-qt-de signer-kdevelop (23.01.2016)

[4] http://www.spiegel.de/forum/wirtschaft/flughafen-berlin-brandenburg-brandschutzex perten-waren-keine-experten-thread-376461-16.html (23.01.2016)

[5] http://www.gea.de/region+reutlingen/reutlingen/banater+schwaben+feiern+kirchweih +in+betzingen.4339490.htm (23.01.2016)

[6] http://paolohor.blogspot.de/2015/10/ein-schulmeister-aus-deutschland-mobbt.html (23.01.2016)

[7] http://www.kirche-koeln.de/aktuell/2391 (23.01.2016)

[8] http://www.tageswoche.ch/de/2014_09/schweiz/647092/ (23.01.2016)

[9] http://www.sta-forum.de/theologie/christentum-und-konfessionen/siebenten-tags-ad ventisten/3654-freiheit-statt-gesetz/index2.html (23.01.2016)

[10] http://www.trennungsschmerzen.de/verlassen-mit-baby-wer-noch-t604.html (24.01.2016)

[11] http://www.spiegel.de/forum/wissenschaft/wissenschaft-den-medien-dafuer-sind-siezu-bloed-thread-129376-14.html (24.01.2016)

[12] http://www.arrcade.de/im-interview-horisont/ (24.01.2016)

[13] http://www.joyclub.de/forum/t302788-165.sex_wie_lange_ist_es_bei_euch_so.html (24.01.2016)

[14] https://books.google.de/books?id=d301AwAAQBAJ\&pg=PT11\&lpg=PT11\&dq=\% 22was+denn+h\%C3\%A4tte+denn\%22\&source=bl\&ots=sKiz4TiNEi\&sig=MjFimbAEgitD_ DPSMwOldnWzRHg\&hl=de\&sa = X\&ved=0ahUKEwiOy5Gdq8LKAhXJiywKHek2AJUQ6AEIHTAA $\# \mathrm{v}=$ onepage\& $\mathrm{q}=\% 22$ was\%20denn\%20h\%C3\% A4tte\%20denn\%22\&f=false (24.01.2016)

[15] http://www.urbia.de/archiv/forum/th-4367193/unsere-nachbarn-rufen-bestimmt-balddie-polizei-wenn-wir-haare-waschen.html (24.01.2016)

[16] http://rebellmarkt.blogger.de/stories/2210381/ (24.01.2016)

[17] http://forum-swiss.blogspot.de/2012_03_01_archive.html (24.01.2016)

[18] http://www.bsmparty.de/forum/thread/751 (24.01.2016)

[19] https://books.google.de/books?id=DvgygAAQBAJ\&pg=PA76\&lpg=PA76\&dq=\% 22 wann+denn+hast+du+denn $\% 22 \&$ source $=$ bl\&ots $=183$ eBpC6ik $\&$ sig $=$ QPewlact00838uahgLLeg9L6kPU\&hl=de\&sa $=$ X\&ved $=$ 0ahUKEwi1oNrni8PKAhVC1iwKHVYRD0kQ6AEIHjAA\#v=onepage \&q=\%22wann\%20denn $\% 20$ hast $\%$ 20du\%20denn\%22\&f=false (24.01.2016) 
[20] http://www.poetry.de/showthread.php?t=44833 (24.01.2016)

[21] http://www.bunnx-exzurück.de/print-id-1725-page-1.html (24.01.2016)

[22] http://www.wallstreet-online.de/diskussion/1122456-19631-19640/blockbuster-beigrant-life (24.01.2016)

[23] http://diskussionen.die-fans.de/nordostfussball/21821-der-vorstellungsthread/5.html (24.01.2016)

[24] https://ask.fm/SchenheitenAusDemLahnDillKreis (24.01.2016)

[25] http://www.film-rezensionen.de/2016/01/point-break-gewinnspiel/ (24.01.2016)

[26] http://forum.golem.de/kommentare/security/landesdatenschuetzer-bei-dashcam-nut zung-drohen-hohe-geldstrafen/was-nur-ist-nur-los-mit-denen/

85300,3837972,3837972,read.html (24.01.2016)

[27] https://books.google.de/books?id=WZgsAQAAQBAJ\&pg=PA365\&lpg=PA365\&dq=\%

22 warum+nur+bin+ich+nur\%22\&source=bl\&ots=tizxsedb4t\&sig=

Cm2sfeSz9iaZ6zi6ywc8zRFV5U\&hl=de\&sa= X\&ved=0ahUKEwilg9_

D88TKAhUFkywKHcz7AE0Q6AEIHDAA\#v=onepage \&q=\%22warum\%20nur\%20bin\%

20 ich $\% 20$ nur\%22\&f=false $(25.01 .2016)$

[28] http://resisweissewelt.blogspot.de/2014/12/leise-rieselt-der-schnee.html (25.01.2016)

[29] http://www.almac.de/forum/archive/index.php/t-13250.html (25.01.2016)

[30] http://www.sciroccoforum.de/forum/archive/index.php/t-326704.html (25.01.2016)

[31] https://books.google.de/books?id=FJexCgAAQBAJ\&pg=PT4\&lpg=PT4\&dq=\%22warum +nur+ist+er+nur\%22\&source=bl\&ots=k0zcNnki7w\&sig=Rn3Cv3MQzyvi5_c1eXJGkBv_

SwE\&hl=de\&sa=X\&ved=0ahUKEwiK8Zn09MTKAhUG1iwKHT2-Ax4Q6AEIHDAA\#v=onepa ge $\& q=\% 22$ warum $\% 20$ nur\%20ist\%20er\%20nur\%22\&f false $(25.01 .2016)$

[32] https://de.answers.yahoo.com/question/index?qid=20090221025612AA4WRZa (25.01.2016)

[33] http://www.purkersdorf-online.at/komm/_da.php?ar=7\&num=02046-00001-0000100002-00001-00001-00000-00000-00000-00000 (25.01.2016)

[34] http://www.forum-ddr-grenze.de/t12633f70-Die-Geschichte-n-der-Wende-2.html (25.01.2016)

[35] https://books.google.de/books?id=gEe7SW5WcbEC\&pg=PT89\&lpg=PT89\&dq=\% 22 warum+nur+war+ich+nur\%22\&source=bl\&ots=z25A_12W1u\&sig= gpaJeZqQdwn6vLWFkQfGUs9xAw\&hl=de\&sa=X\&ved= 0ahUKEwjk1YPb9cTKAhXDkywKHWa5DG8Q6AEIHDAA\#v=onepage\&q=\%22warum $\%$ 20nur\%20war\%20ich\%20nur\% 22\&f=false (25.01.2016)

[36] https://books.google.de/books?id=XFvCgAAQBAJ\&pg=PT87\&lpg=PT87\&dq=\% 22warum+nur+war+er+nur\%22\&source=bl\&ots=RIqxLp4IDD\&sig=1qSN3kzXHKsQ738mtopjFaP9X4\&hl=de\&sa=X\&ved=0ahUKEwj-m-D_ 9cTKAhWDWiwKHS9-Dk4Q6AEIHDAA\#v=onepage \&q=\%22warum $\% 20$ nur $\% 20$ war $\% 20 \mathrm{er}$ \%20nur \%22\&f=false (25.01.2016)

[37] https://www.wattpad.com/78507062-i-wish-larry-german-au-kapitel-19 (25.01.2016)

[38] http://blog.gwup.net/2014/12/12/globale-erwarmung-leugner-sind-keine-skeptiker/ $(25.01 .20$

[39] http://www.taucher.net/edb/SUB_AQUA_DiveCenter_Utopia_Beach_b113_be richt11874.html (25.01.2016)

[40] https://m.facebook.com/CDU/posts/10153194594340415?comment_id= $10153194605140415 \&$ offset $=0$ \&total_comments $=51 \&$ comment_tracking $=\{\% 22 \operatorname{tn} \% 22 \%$ $3 A \% 22$ R0\%22\}\%20 (25.01.2016) 
[41] http://www.myfanfiction.net/de/t/132389/him/last_love.haben_wir_nicht_schon_ alles_gespuert.710713.html (25.01.2016)

[42] https://meta.tagesschau.de/id/102198/merkel-will-in-heidenau-mit-fluechtlingen-spre chen (25.01.2016)

[43] http://www.fanfiktion.de/s/4f53ed0a000215a20c903a98/1/Sie-hat-mir-dein-Herz-ges tohlen (25.01.2016)

[44] http://www.fanfiktion.de/s/42f66a9700001837067007d0/1/Just-Love-Me- (25.01.2016)

[45] http://www.welt.de/vermischtes/article139978959/Eltern-lassen-an-Krebs-verstor bene-Zweijaehrige-einfrieren.html (25.01.2016)

[46] https://twitter.com/kc_dc/status/671766956152856576 (25.01.2016)

[47] http://www.trendmile.de/gedichte/Herz_Schmerz72.php (25.01.2016)

[48] http://forum.rotetraenen.de/index.php/Thread/24789-schauspieler/?pageNo=2 (25.01.2016)

[49] https://www.google.de/url?sa=t\&rct=j\&q=\&esrc=s\&source=web\&cd=1\&ved= 0ahUKEwjw5srahMXKAhVlfywKHQiEB1AQFggfMAA\&url=https\%3A\%2F\%2F www.fanfiction. net\%2Fs\%2F2379536\%2F2\%2FSnapes-Girl\&usg=AFQjCNF9e1VmNLIW0-iFowGNCOel-BoDeg (25.01.2016)

[50] https://www.wattpad.com/63478826-mps-slow-updates-14-kill-the-leader-gewalt/ page/3 (25.01.2016)

[51] https://books.google.de/books?id=r4QhCwAAQBAJ\&pg=PT1870\&lpg=PT1870\&dq=\% 22 wer+schon+h\%C3\%A4tte+schon $\% 22 \&$ source=bl\&ots=WILJ90dk19\&sig= qQwFZxfSvc4qpJc4kee052vyK8U\&hl=de\&sa=X\&ved= 0ahUKEwiX8vLkjMDKAhWEGCwKHcqxDnAQ6AEIHzAA\#v=onepage \&q=\%22wer\% 20schon\%20h\%C3\%A4tte\%20schon\%22\&f=false (23.01.2016)

[52] http://www.wrestling-infos.de/board/showthread.php?t=25441 (23.01.2016)

[53] http://politik-forum.eu/viewtopic.php?p=2455063 (23.01.2016)

[54] http://www.nordbayerischer-kurier.de/nachrichten/merk-erbe-verlangt-entschuldi gung-von-specht_99446 (23.01.2016)

[55] http://m.lifeline.de/expertenrat/frage/Forum-Wechseljahre/-Alle-?threadld= 185124\&pageNumber $=3$ (23.01.2016)

[56] http://www.welt.de/regionales/hamburg/article119623046/Schwerer-Unfall-auf-der-A23-Totgeglaubte-lebt.html (23.01.2016)

[57] http://www.rc-network.de/forum/archive/index.php/t-308057.html (23.01.2016)

[58] https://de-de.facebook.com/DSDS/posts/10153151543198221 (23.01.2016)

[59] http://www.chefduzen.de/index.php?action=printpage;topic=12793.0 (23.01.2016)

[60] http://homematic-forum.de/forum/viewtopic.php?t=28480\&p=254238 (24.01.2016)

[61] http://www.dual-board.de/index.php?thread/15178-auswirkung-der-zarge-auf-denklang/ (24.01.2016)

[62] http://www.rp-online.de/sport/fussball/em/dfb/deutschland-am-boden-aid-1.476221 (24.01.2016)

[63] http://www.heise.de/forum/heise-online/News-Kommentare/Abgas-Skandal-VWUmruestungsplan-verbluefft-Experten/Re-Wirklich-Betrug-bei-VW/posting-23962919/ show/ (24.01.2016)

[64] http://www.essenspausen.com/die-pharma-mafia-lebensmittel-und-hormone/ (24.01.2016)

[65] http://derstandard.at/1348284457159/Rebellen-greifen-Armeestuetzpunkt-in-Aleppoan (24.01.2016) 
[66] https://www.boote-forum.de/showthread.php?t=12621 (24.01.2016)

[67] http://www.computerbase.de/forum/showthread.php?t=331054\&page=2 (24.01.2016)

[68] http://www.spiegel.de/forum/politik/kritik-westerwelle-borniertester-aussenministerseit-von-ribbentrop-thread-34151-44.html (24.01.2016)

[69] http://www.1000steine.de/de/gemeinschaft/forum/?entry=1\&entrylink=1\&id= 186334\&PHPSESSID=f6e17f27968b4568933119b9d416b169 (24.01.2016)

[70] http://www.wallstreet-online.de/diskussion/500-beitraege/112858-1-500/uvgi-neuerthread (24.01.2016)

[71] http://community.eintracht.de/forum/diskussionen/12216?page=3 (24.01.2016)

[72] http://uhrforum.de/seiko-snke01k1-bezugsquelle-oder-fuer-seiko-allgemein-t189992 (24.01.2016)

[73] http://www.20min.ch/talkbacks/story/17700456 (24.01.2016)

[74] http://www.radarforum.de/forum/index.php/topic/49737-verkehrskontrolle-mit-restthc-im-blut/page-2 (13.12.2018)

[75] https://www.20min.ch/community/storydiscussion/messageoverview.tmpl?stryid= 17700456\&type $=1 \& \mathrm{l}=0 \&$ channel=de/schweiz $(03.12 .2018)$

[76] https://wuerzedeinleben.wordpress.com/category/ketonix/ (16.06.2016)

[77] https://blog.campact.de/2014/01/danke-baden-wuerttemberg/ (16.06.2016)

[78] https://forum.hirntumorhilfe.de/neuroonkologie/erfahrung-mit-ttf-8386.html (16.06.2016)

[79] http://www.pi-news.net/2014/12/bargeldverbot-bedeutet-verlust-der-freiheit/ (16.06.2016)

[80] http://www.pi-news.net/2014/04/inklusion-2-henri-geistig-behindert-will-ans-gymna sium/ (16.06.2016)

[81] https://appleinsider.com/articles/18/07/02/review-marshall-multi-room-speakerssound-great-but-lack-airplay-2 (20.11.2018)

[82] https://www.dailydot.com/upstream/netflix-original-movies-2018/ (20.11.2018)

[83] https://alliesinrecovery.net/2015/12/coping-with-negative-feelings-around-a-lovedones-addiction/ (20.11.2018)

[84] https://literaturgefluester.wordpress.com/category/literaturbetrieb/ (05.12.2018)

\section{References}

Barbiers, Sjef. 2010. Focus particle doubling. In Jan-Wouter Zwart \& Mark de Vries (eds.), Structure Preserved: Studies in Syntax for Jan Koster, 21-29. Amsterdam:

John Benjamins.

Barbiers, Sjef. 2014. Syntactic doubling and deletion as a source of variation. In M. Carme Picallo (ed.), Linguistic Variation in the Minimalist Framework, 197-223. Oxford: Oxford University Press.

Bayer, Josef. 1996. Directionality and Logical Form: On the Scope of Focusing Particles and Wh-In-Situ. Dordrecht: Kluwer.

Bayer, Josef. 1999. Bound focus in German or how can association with focus be achieved without going semantically astray?. In Georges Rebuschi \& Laurice Tuller (eds.), The Grammar of Focus, 55-82. Amsterdam: John Benjamins.

Bayer, Josef. 2010. Wh-drop and recoverability. In Jan-Wouter Zwart \& Mark de Vries (eds.), Structure preserved: Studies in Syntax for Jan Koster, 31-39. Amsterdam: John Benjamins. 
Bayer, Josef. 2012. From modal particle to interrogative marker: a study of German denn. In Laura Brugè, Anna Cardinaletti, Giuliana Giusti, Nicola Munaro \& Cecilia Poletto (eds.), Functional heads (The Cartography of Syntactic Structures 7), 13-28. Oxford: Oxford University Press.

Bayer, Josef. 2018. Criterial freezing in the syntax of particles. In Jutta Hartmann, Marion Jäger, Andreas Kehl, Andreas Konietzko \& Susanne Winkler (eds.), Freezing: Theoretical Approaches and empirical domains, 225-263. Berlin \& New York: Mouton de Gruyter.

Bayer, Josef, Jana Häussler \& Markus Bader. 2016. A new diagnostic for cyclic wh-movement. Discourse particles in German questions. Linguistic Inquiry 47(4). 591-629.

Bayer, Josef \& Probal Dasgupta. 2016. Emphatic topicalization and the structure of the left periphery: Evidence from German and Bangla. Syntax: A Journal of Theoretical, Experimental and Interdisciplinary Research 19. 309-353.

Bayer, Josef, Probal Dasgupta \& Sibansu Mukhopadhyay. 2014. Functional structure and the Bangla discourse particle to. 30th South Asian Languages Analysis Roundtable (SALA 30), University of Hyderabad, 6-8 February 2014. [handout].

Bayer, Josef \& Hans-Georg Obenauer. 2011. Discourse particles, clause structure, and question types. The Linguistic Review 28. 449-491.

Bayer, Josef \& Andreas Trotzke. 2015. The derivation and interpretation of left peripheral discourse particles. In Josef Bayer, Roland Hinterhölzl \& Andreas Trotzke (eds.), Discourse-oriented Syntax, 13-40. Amsterdam: John Benjamins.

Büring, Daniel \& Katharina Hartmann. 2001. The syntax and semantics of focus-sensitive particles in German. Natural Language \& Linguistic Theory 19. 229-281.

Cardinaletti, Anna. 2011. German and Italian modal particles and clause structure. The Linguistic Review 28. 493-531.

Chomsky, Noam. 1995. The Minimalist Program. Cambridge, MA: MIT Press.

Coniglio, Marco. 2008. Modal particles in Italian. University of Venice Working Papers in Linguistics 18. 91-129.

Coniglio, Marco. 2011. Die Syntax der deutschen Modalpartikeln: Ihre Distribution und Lizensierung in Haupt- und Nebensätzen. Berlin: Akademie-Verlag.

Dikken, Marcel den \& Anastasia Giannakidou. 2002. From hell to polarity: “Aggressively nonD-linked" wh-phrases as polarity items. Linguistic Inquiry 33. 31-61.

Egg Markus \& Johannes Mursell. 2017. The syntax and semantics of discourse particles. In Josef Bayer \& Volker Struckmeier (eds.), Discourse particles: Formal approaches to their syntax and semantics, 15-48. Berlin \& Boston: De Gruyter.

Endo, Yoshio. to appear. Exploring right/left peripheries: Expressive meanings in questions. In Josef Bayer \& Yvonne Viesel (eds.), Clause typing and the syntax-to-discourse relation in head-final languages University of Konstanz. Arbeitspapiere des Fachbereichs Linguistik.

Frascarelli, Mara 2010. Narrow Focus, clefting and predicate inversion. Lingua 120. 2121-2147.

Grohmann, Kleanthes \& Dalina Kallulli. 2006. A case study in syntax-semantics isomorphy: Some thoughts on existential bare plural subjects. QDLF Università di Firenze. 1-15.

Haegeman, Liliane. 1995. The Syntax of Negation. Cambridge: Cambridge University Press. Hentschel, Elke. 1986. Funktion und Geschichte deutscher Partikeln. Ja, doch, halt und eben. Tübingen: Niemeyer.

Jacobs, Joachim. 1983. Fokus und Skalen. Tübingen: Niemeyer.

Klima, Edward. 1964. Negation in English. In Jerry A. Fodor \& Jerrold J. Katz (eds.), The structure of language: Readings in the philosophy of language, 246-323. Englewood Cliffs, NJ: Prentice-Hall. 
Li, Boya. 2006. Chinese Final Particles and the Syntax of the Periphery. Leiden: LOT dissertation 133.

Manzini, Rita M. 2015. Italian adverbs and discourse particles: between recategorization and ambiguity. In Josef Bayer, Roland Hinterhölzl \& Andreas Trotzke (eds.), Discourseoriented Syntax, 93-120. Amsterdam: John Benjamins.

Meibauer, Jörg. 1994. Modaler Kontrast und konzeptuelle Verschiebung: Studien zur Syntax und Semantik deutscher Modalpartikeln. Tübingen: Niemeyer.

Munaro, Nicola \& Cecilia Poletto. 2003. Ways of clausal typing. Rivista di Grammatica Generativa 27. 87-105.

Paul, Waltraud \& Victor Pan. 2017. What you see is what you get: Chinese sentence-final particles as head-final complementizers. In Josef Bayer \& Volker Struckmeier (eds.), Discourse particles: Formal approaches to their syntax and semantics, 49-77. Berlin \& Boston: De Gruyter.

Pesetsky, David. 1987. Wh-in-situ: Movement and unselective binding. In Eric J. Reuland \& Alice G. Ter Meulen (eds.), The representation of (in)definiteness, 98-129. Cambridge, MA: MIT Press.

Poletto, Cecilia. 2000. The higher functional field. Oxford: Oxford University Press.

Poletto, Cecilia \& Vanelli, Laura. 1995. Gli introduttori delle frasi interrogative nei dialettiitaliani settentrionali. In Emanuele Banfi, Giovanni Bonfadini, Patrizia Cordin \& Maria Iliescu (eds.), Italia settentrionale: Crocevia di idiomi romanza, 145-158. Tübingen: Niemeyer.

Reis, Marga. 2005. On the syntax of so-called focus particles in German - A reply to Büring and Hartmann 2001. Natural Language \& Linguistic Theory 23. 459-483.

Rizzi. Luigi. 1990. Relativized Minimality. Cambridge, MA: MIT Press.

Rizzi, Luigi. 1991/1996. Residual verb second and the Wh-Criterion. In Adriana Belleti \& Luigi Rizzi (eds.), Parameters and Functional Heads, 63-90. New York: Oxford University Press.

Rochemont, Michael. 2018. Only syntax. In Jutta Hartmann, Marion Jäger, Andreas Kehl, Andreas Konietzko \& Susanne Winkler (eds.), Freezing: Theoretical Approaches and empirical domains, 264-283. Berlin \& New York: Mouton de Gruyter.

Rooth, Mats. 1985. Association with Focus. Amherst, MA: University of Massachusetts Ph.D. dissertation.

Rooth, Mats. 1992. A theory of focus interpretation. Natural Language Semantics 1. 75-116.

Smeets, Liz \& Michael Wagner. 2017. The syntax of focus association in Dutch and German: Evidence from scope reconstruction. West Coast Conference on Formal Linguistics (WCCFL) 34. 470-480.

Taglicht, Joseph. 1984. Message and emphasis: On focus and scope in English. London: Longman.

Thurmair, Maria. 1989. Modalpartikeln und ihre Kombinationen. Tübingen: Niemeyer.

Trotzke, Andreas. 2017. The Grammar of Emphasis. From Information Structure to the Expressive Dimension. Berlin \& New York. Mouton de Gruyter.

Trotzke, Andreas \& Giuseppina Turco. 2015. The grammatical reflexes of emphasis: evidence from German wh-questions. Lingua 168. 37-56. 